action-based as well as advancing the frontiers of scientific knowledge" (Burnett et al., p. 341). These technical and local studies explore the positive ways information can be used by the actors involved. Knowing differences in water content of soil under rubber, tea, secondary forest and grassland sites, for example (GuardiolaClaramonte et al., p. 245) is important for policy. Understanding how feral pigs lead to mosquito proliferation (by consuming the inner cores of native ferns [Bruland et al., p. 256]) is important for policy.

When governments are able to access solid science and the 'knowledge systems' of scientists, they are able to make policies that are beneficial. There is still a political dimension for activists, but certainly there is a need for policy-relevant science. This volume is an important start toward the integration of science and policy.

\title{
Jonas Adelin Jørgensen, Jesus Imandars and Christ Bhaktas: Two Case Studies of Interreligious Hermeneutics and Identity in Global Christianity. Studies in the Intercultural History of Christianity 146
} (Frankfurt am Main: Peter Lang, 2008). xii+481 pp. ISBN: 9783631584866. US\$107.95

\section{Mika Vähäkangas Centre for Theology and Religion, Lund University}

The end of colonialism, the previously unparalleled level of religious plurality due to both migration and internal diversification of various societies, and lastly the shift of the centre of gravity to the global South in terms of the membership of Christian churches are changes with which Western academic Christian theology has to come to grips with. The high tide of colonialism, and its theological equivalent ethnocentric religious arrogance - was followed by the end of colonial era, reflected also in theology. When one combined the suddenly grown religious pluralism in the West and the remorse for the colonial past an outcome was a number of liberal (or, at times, seemingly liberal) pluralistic or relativistic theologies of religion. That could be called 'post-colonial' in the sense of being epi-colonial.

To reach a real post-colonial stage in theologies of religions, i.e. leaving colonial heritage behind, a new generation seems to be needed - born after the colonial era, and to whom religious plurality is a self-evident fact. Jonas Adelin Jørgensen, a Copenhagen missiologist and systematic theologian, belongs to that generation. He analyses the faith and the practice of two types of believers on the border-zone between Christianity and other religions: Jesus imandars of Dhaka, Bangladesh and Christ bhaktas of Chennai, India. They both confess Jesus as their focus of faith while clinging to their identities as Muslims and Hindus. 
Jørgensen has collected a highly interesting corpus of interview and observation material from both cities, from several groups. The outcome of his description and analysis of the sources is that while these followers of Christ reject organisational Christianity, in the content of faith they come surprisingly close to (some forms) of especially Protestant internalised piety. His interpretation of their faith does not at least overemphasise their variation from what in the West has been labelled as 'classical Christianity'. Jørgensen's treatment of the Jesus imandars and Christ bhaktas makes highly interesting reading, even though it contains relatively much redundant material due to a rather rigid form of presentation.

However intriguing the analysis of empirical data is, his study contributes more to systematic theology. Jørgensen breaks the old western tradition of philosophy as the primary discussion partner to theology, and rather makes use of empirical realities, like in much of the Two-Thirds World theology. Unlike some older liberation theologies discussing with social theories, Jørgensen bases theological debate on his own research, done in order to feed data to theological discussion.

There are a number of theological insights provided by this approach. Firstly, in these cases contextualisation takes place through a syncretistic process, and the author considers contextualisation to be a syncretistic process by nature. The syncretistic nature of the process, however, does not necessarily result in doctrinally "illegitimate" syncretism, Jørgensen argues. What remains open, however, is what are the exact limits and criteria for 'legitimate' syncretism in terms of doctrine. Secondly, syncretism should not be understood as an opposite of Christian identity but rather as a way of constructing a relevant Christian identity. This is understandable when considering the previous point because a goal of contextualisation is construction of a viable local Christian identity. Thirdly, this syncretistic process between foreign Christian and local non-Christian traditions takes place in a multi-faceted way, i.e. the same people use several different strategies to work on their world-views and identities. This need not mean internal contradictions but rather that the believer is able to locate issues on different levels. Fourthly, the fact that one is committed to his faith does not necessarily make him a rigorous bigot. Rather, commitment may serve as a foundation for openness for change and learning from other religious traditions.

Jørgensen moves on to produce a sketch of a model for interreligious hermeneutics on the basis of his findings. The outcome is interesting, and it serves as a fresh start for another round of considerations on theology of religions. One remains looking forward to how he will develop his ideas further.

Despite the number of typos and grammatical mistakes and the sheer length of the book, Jørgensen's study belongs to the list of highly recommended studies on interreligious relations. 